\title{
The Performative Power of Queer Assemblies
}

\section{Pablo Pérez Navarro}

Krisis 40 (1): 165-179.

\begin{abstract}
This paper addresses some relations between the spatial politics of queer assemblies in spaces of protest and the constitution of collective political subjects. It does so by exploring the spatial politics of queer activism within the global Occupy movements, in the light of Judith Butler's work on the performative power of assembly and the ambivalences of the Foucauldian concept of heterotopia. Specific challenges faced by queer activists in various encampments will be addressed in order to expose some tensions between the constitutive exclusions inherent to the constitution of spaces of protest and the processes of coalition building needed to effectively overcome those very constitutive exclusions.
\end{abstract}

\section{Keywords}

Heterotopia, Protest space, Public assembly, Queer activism, Constitutive exclusions

DOI

$\underline{10.21827 / \text { krisis. } 40.1 .36972}$

\section{Licence}

This work is licensed under a Creative Commons Attribution-NonCommercial 3.0 License (CC BYNC 3.0). 


\section{The Performative Power of Queer Assemblies}

\section{Pablo Pérez Navarro}

Utopias afford consolation: although they have no real locality there is nevertheless a fantastic, untroubled region in which they are able to unfold; they open up cities with vast avenues, superbly planted gardens, countries where life is easy, even though the road to them is chimerical. Heterotopias are disturbing, probably because they secretly undermine language, because they make it impossible to name this and that, because they shatter or tangle common names, because they destroy 'syntax' in advance, and not only the syntax with which we construct sentences but also that less apparent syntax which causes words and things (next to and also opposite one another) to 'hold together'.

Michel Foucault

\section{Introduction: Zooming Out from Madrid}

Nearly a decade has passed since the night of May 152011 when a small group of people assembled at Puerta del Sol - the iconic square in central Madrid and the very heart of the city - to set up camp. Earlier that day, the streets of the capital were agitated by a protest organized by a mix of emerging political groups (see Fiexa 2013), but their incipient encampment would come to be violently dismantled by the police one night later. As a result, on May 17, thousands of people returned to the square, gathering to form the camp known as Acampada Sol. This event, which gave rise to the Indignados, or $15 \mathrm{M}$, movement, took on a dimension that would have been impossible to anticipate just a few hours before. In the days following, similar camps proliferated in no fewer than 219 cities across Spain (Nofre 2013). Spanish sociologist Manuel Castells commented on the contagious character of the encampments in a speech given at Barcelona's Plaza de Cataluña, twelve days after the camp had been established at Puerta del Sol, noting how quickly the encampments were multiplying, not only in Spain, but also abroad: "what we are experiencing here, and in the more than 706 camps around the world, [is something that] has substance, has roots, and whatever forms it takes and whatever will happen, this movement will continue" (Castells 2011) ${ }^{1}$.

And he was certainly right. Following the impulse of the Arab Spring, the succession of movements and encampments would soon come to include such key nodes as Syntagma Square in 
Athens, where the already ongoing protests adopted the "camp model" in June: "the $15 \mathrm{M}$ [movement] was to become the "resonator" that set in motion the relevant mechanisms for the birth of a mass movement-culminating 10 days later in the occupation of Syntagma Square" (Oikonomakis and Roos 2013). Four months later, the occupation of Zuccotty Park in New York gave birth to the so called "Occupy Movement", which was also clearly influenced, as was the $15 \mathrm{M}$, by the Arab Spring. The influence of the latter is a common reference, but it has also been argued that "the Indignados movement in Spain is a direct precedent and inspiration for the Occupy movement in the USA, even when such a link is rarely spelled out" (Castañeda 2012, 309). In any case, the wave of occupations in the Occupy movement also spread abroad, including one of the most long-lasting encampments, Occupy London, whose transcontinental flux of influences encompassed "the recent experiences of the Spanish Indignados, the prior Arab Spring and of course the inception of Occupy itself in New York" (Halvorsen 2012, 428). A similar mix of influences can be traced in the camp in Gezy Park, Istanbul, settled in May 2013, during which "as with the indignados "breaking the silence" in Spain and the Occupy movement in Wall Street, a new way of living was prefigured at the symbolic center of the capital" (Barnett 2013). And a similar argument could be made about more recent movements, such as the Umbrella Revolution, born when the movement Occupy Central with Love and Peace decided to set up camps at major intersections of Hong Kong's Central Business District, renaming it Umbrella Square (Barber 2014), and whose critical impulse was renewed during the 2019-2020 Hong Kong protests.

A common feature of this cycle of protests sharing the "camp model", which for the sake of simplicity I will call global occupy movements ${ }^{2}$, is the way they spectacularized the relationship between making their collective demands visible and politically intelligible and the - only apparently - more material struggle over the public character of certain strategical spaces of the city. For instance, the semantic accent of one of the most repeated slogans at Puerta del Sol during the $15 \mathrm{M}$ movement, "it is not a crisis, it is a scam", highlighted the collective rejection of the official narrative justifying the government's endorsement of austerity politics. In a way, therefore, the protest could be read as a struggle over the terms of a narrative depicting the victims of the economic crisis as responsible for their very own dispossession of material and political rights. At the same time, on the other hand, as Judith Butler has discussed at length in Notes Toward a Performative Power of Assembly, the articulation of a plural 
political subject such as this one often depends upon its capacity for bodily occupying the strategic public spaces of the city. Moreover, insofar as occupation implies a struggle over the public character of public space, it is implied in a broader struggle against the dispossession of public, common goods for the benefit of private interest. In that sense, the sustained occupation of countless squares and the transformation of camping into a practice of civil disobedience has a powerful performative meaning in and of itself, and was always already a constitutive element of the political narrative advanced by the protest as a whole.

Notwithstanding this, if we examine the occupy movements more closely, this kind of right to the city has been shown to imply a great inner complexity that, from the outset, defies any superficial reading of slogans such as "We are the 99\%". Indeed, a good way to counter reductionist depictions of the encampments' spatial politics is to question who can be considered part of the collective struggle, as it were, from the start, and whose place within the protest implies a prior struggle for the right to appear within the space of the protest itself. As a result, a whole field of tensions and constitutive exclusions emerges, and that has over time been explored from different perspectives considering vectors such as gender (Salime 2016), racism and postcolonial struggles (Brady and Antoine 2012), class and homelessness (Schein 2012), or migrant status (Nair 2012), to name but a few. In the following, with the aim of further reflecting upon the relationship between the articulation of a plural political subject and the spatial politics of the protest, I will focus on a source of such tensions, (but also synergies), that have received little academic attention. As I hope to show, the organization of queer activism in specific assemblies within the Occupy movements occupies a strategical place when it comes to understanding the role played by particular collectives and groups of people in the process of production, to use the Lefebvrian formula (1991), of the space of the protest as a whole. With the purpose, therefore, of exploring what the gatherings of queer bodies can teach us about the spatial dynamics of the Occupy movements, I will focus on the processes of irruption of queer assemblies in the protest camps settled in various cities, including Madrid, during the 15M Movement, Austin, during the Occupy Movement, and Istanbul, at the Gezi Park protests.

\section{Of other (queer) spaces}

Foucault in 1967 dedicated a conference to the concept of heterotopia, entitled "Of Other Spaces". There, he offered a discussion of those spaces that work as "a kind of effectively 
enacted utopia" (Foucault 1986, 24). He contrasted utopias, conceived as ideal, imaginary spaces, with heterotopias, thought of as places that in "real" space introduce those forms of social alterity that we usually associate with the political and literary topic of utopia. "Enacted" utopias, therefore, that establish a critical relation with the space in which they emerge: heterotopias share "the curious property of being in relation with all the other sites, but in such a way as to suspend, neutralize, or invert the set of relations that they happen to designate, mirror, or reflect" (24). It is in their relational character where Foucault more clearly highlighted the most politically meaningful possibilities inherent to the spatial alterities that he had in mind.

When it comes to understanding protest camps, it becomes necessary to relate the Foucauldian suggestion that heterotopias establish a critical relationship "with all other sites" with regard to the urban character of the movements to which they belong. With this in mind, the reference to "all other sites" refers, in the first place, to the space of the very same cities in which the emergence of the protest camps takes place. Not surprisingly, the maps of some protest encampments have been compared with that of the ancient Greek camp-cities (Nofre 2013). Considering their urban character, their utopian impulse would necessarily rely on the critical inversion of the institutional life in the neoliberal city through radically democratic assemblystyle politics, this being an inversion that, nonetheless, is not exempt from inner tensions that the unavoidable ambivalence of the concept of heterotopia helps to take into account ${ }^{4}$. As for dealing with these kinds of, let us say, structural ambivalences, the ways Judith Butler extends her readings of relationality of gender and bodily performativity to the political effects of the assemblage of bodies in scenarios of protest offers some fundamental points of reference. Drawing on Hannah Arendt's understanding of the "space of appearance" of bodies who assemble in democratic political action, Butler calls our attention to the relations of power -and the constitutive exclusions ${ }^{5}$ - through which public assembly spaces are produced in the first place. Through that lens, looking at the specific ways the space of the protest is produced becomes a central question when it comes to understanding what is going on, in political terms, in any form of street protest. For example, when reflecting on the spatial politics of the Tahrir Square encampment, Butler describes the methodical differentiation of the space of the square as one that, "overcoming class and gender inequalities" in relation to the distribution of tasks was actually producing a "different space" to "Mubarak's regime and its entrenched 
hierarchies". The space of the protest would be, in this sense, a heterotopia (Foucault 1986) of resistance produced through a coming together that performatively brings "the space of appearance into being” (Butler 2011, 89).

This bodily "bringing into being" is a key element when considering the strategies through which the attempt to build egalitarian relationships within the space of the camp occurs. This is quite relevant with respect to those spaces of the protest camps where some gather in assembly to face oppressions and forms of violence that are unique for being experienced also within the limits of the space of the protest.

The settlement of the large feminist tent within Acampada Sol is a good example of a critical spatial differentiation within the space of the protest. As stated in the dossier of the feminist assembly of the 15M Movement in Madrid, Feminismos Sol, it was only through the settling of "a tent of their own", to paraphrase Virginia Woolf, that the formation of the feminist assembly was made possible. By claiming its own space within the space of the protest, feminist activists were, in a way, taking very seriously Jacques Rancière's definition of political activity as a bodily action that "changes a place's function" in order to make "understood as discourse what was once only heard as noise" (Rancière 1999, 30).

Also within the limits of Acampada Sol, there was another group committed to the politicization of gender and sexual differences: the Transmaricabollo [transfagdyke] de Sol assembly. Even if it did not occupy a differentiated space in the form of a tent, the gathering of activists in its assemblies also represented the "bringing into being" of a queer space within the encampment. Similar to the way that Feminismos Sol struggled with gender inequalities within Acampada Sol, this assembly played an important role in the queerification of the space of the camp (Pérez Navarro 2014, 93).

Unlike most other work groups of the movement, both the feminist and the queer assembly shared a mutual determination to develop a bidirectional work: the formation of both assemblies can actually be read as the constitution of new spaces of resistance within the encampment, confronting sexism and "queer-phobia" common to the city as a whole and to the camp itself. As was already the case for feminist activism in the uprisings of the Arab Spring (Benyoussef 2016), the gathering of bodies in both assemblies greatly exemplifies the need, for certain collectives, to occupy spaces of their own in order to render political action possible 
while contributing, as Gracia Trujillo puts it, to a critical overcoming of the "hegemonic subject of social protest" (Trujillo 2016, 14).

In this sense, one of the common aspects to the spatial politics of queer heterotopias (Jones 2009) within massive citizen protests is the double directionality of their political impact: toward the space of the city and toward the space of the protest (Pérez Navarro 2014, 89). It is in that sense that it can be said that queer assemblies in the global Occupy movements, much like the Pink blocs of the counter-globalization movement did, frequently produced a lasting queerification of the movements they have participated in (Pérez Navarro 2017, 197). As for the $15 \mathrm{M}$ movement, it is worth noticing that the Transmaricabollo Assembly is one of the few work groups from the movement that are still active today. Since then, the assembly has worked in coalition with other groups of the movement and, notably, with other queer collectives from Madrid involved in the organization of an annual Critical Pride (Trujillo 2017). At the same time, the assembly has been quite active in establishing coalitions with other groups, such as those working in the sex workers' rights movement, antifascist groups and collective struggles against the increasing criminalization of the protest in the repressive context of the gag laws implemented by the government as a response to the $15 \mathrm{M}$ movement itself.

\section{Inner coalitions}

The production of feminist and queer spaces in many other encampments ${ }^{6}$ has played a major role in the struggle against what some perceive as a failure of the encampments "to engage with race, class, and other disparities that stratify the $99 \%$ or otherwise mobilize broad based coalitional support in furtherance of the movement" (Jaleel 2014). As expressed by the editors of the volume Freedom Without Permission, Bodies and Space in the Arab Revolutions, drawing on feminist geography, these inner struggles would force us to think of the political as an agonistic space which includes "out of place" embodiments, such as when black, pregnant, disabled, poor, homeless, or otherwise nondominant or nonconforming people enter hegemonic spaces" (Hasso and Salime 2016).

The queer assembly in the Occupy Austin's encampment is another good example. As Holly Lewis explains in "Occupy Gender: How Women and Queer People Find Their Voice in Mass Movements" (Lewis 2011), the refusal of Occupy Austin's general assembly to address LGBTQ phobic violence in systemic terms, rather than as an episodic problem, incited many 
women and queer people to start to abandon the encampment. Evidencing that the well-intended presuppositions on the "radical inclusivity" of the movement, typically accompanied by a fear of the divisive effects that the diversification of political voices could entail, in addition to the "failure to address gender and racial injustice", was, at the end, what "divided, weakened, and disengaged the movement" (Lewis 2011, 129). The subsequent formation of the OccuQueers assembly encouraged women and queer people to "rejoin the movement as a novel, for-itself force" (p. 129, my emphasis), not only by producing safe spaces for women and queer protesters but also by granting, through a frequent participation in the general assembly that became "routine in Occupy Austin", that "such blatant anti-woman and anti-queer sentiment [was] no longer tolerated" (Lewis 2011, 129).

Holly Lewis uses the expression "for-itself" in what she describes as a Marxian sense for which "the articulation of a class for-itself occurs through the process of political mobilization and struggle itself: the process of struggle shapes the being of the collective"7 (Lewis 2011, 117). This approach would serve the purpose of avoiding any essentialist pre-definition of those who are supposed to be included in the constitution of what she refers to, nonetheless, as a "women's voice", in the understanding that "closing ranks through asserting the demands of the most vulnerable populations solidifies women as a unit and helps thwart political disintegration", a goal which would be "valuable because such actions help the group cohere and develop into a for-itself entity" (Lewis 2011, 123).

However, one can wonder what a "for-itself force" actually means in terms of the emergence of queer activism, given that the blurring between any "for-itself" politics and "external" coalition building is, typically, a constitutive part of queer politics: the more "for-itself" they get, the more the bonds with a heterogeneous spectrum of oppressions start to proliferate from its very core. One of the particularities of queer activism is its tendency to undermine distinctions between "internal" and "external" differences in such a way that its political subject can no longer be conceived "as a unit" in any meaningful sense, even though the "incohesiveness" of the subject of queer politics is not at odds with the relations it establishes with specific forms of gender and sexual differences. In fact, the productive tensions that arise from the embodiment of highly specific subject positions and the expansive proliferation of queer subjectivities has been a distinctive feature of queer activism since the AIDS crisis, when AIDS and HIV- 
positive related struggles became the occasion for the establishment of unprecedented forms of solidarity and coalition-building via the entire spectrum of class, race, sexual, and gender differences. In this sense, when read in terms of the formation of political subjects through coalitional practices, the Foucauldian characterization of heterotopias as spaces which establish a critical relation with "all other spaces" serves as a sound spatial metaphor for the ungroundable, incohesive character of the queer subject.

In the case of OccuQueers, this tendency is already implicit in their self-definition as a group "encompassing activists identifying as lesbian, gay, bisexual, transgender, genderqueer, asexual, intersexual, leather, polyamorous, kinky and other non-heteronormative sexual orientations, lifestyles, and identities as well as straight allies" (Occuqueers 2011, June 10), but also reflected in their direct involvement in the struggle against a wide set of overlapping forms of oppression. The list includes, but is not limited to, their coalition with the disability rights activist group OccuKripz; with End Homelessness for housing-related struggles and their participation, including organizational tasks, in theatrical actions and the production of audiovisual resources; in the protest OccupyAustin Welcomes Obama -denouncing the United States' use of drones and "his policy of killing anyone anywhere without due process" (Occuqueers 2011, July 31); - among other forms of coalition building. Even if some of them are in fact deeply infused with issues of gender and sexual discrimination, such as the politics of homelessness, to the point that they can be read as part of the constitution of the group in a relatively self-centered point of view, it is also true that seriously engaging with any of these struggles ends up by exceeding any possible conception of cohesive, "for-itself" conception of politics. Therefore, even if one were to agree that in the case of the articulation of a "women's voice", "closing ranks through asserting the demands of the most vulnerable populations solidifies women as a unit and helps thwart political disintegration" (Lewis 2011, 123), the articulation of queer voices, on the contrary, frequently entails the determined "disintegration" of any meaningful conception of the queer subject as a "unit".

\section{Cruising the neoliberal city}

The case of the Gezi uprising in Turkey is, from the point of view of this last concern, paradigmatic. The project to build a shopping center in the Beyoğlu district was the latest episode in a gentrification process of the area that had been ongoing at least since the 1980s, one which already carried a memory of "dispossession and displacement" (Nahrworld And Bayhan, 2013, 
134) for both different ethnic groups (Roma, Kurds) and sexual minorities that had been especially violent for transgender people living in Tarlabasi's "transgender slum" (Carter 2015). Nonetheless, despite the intensity of the "conservative restructuring of public space" (Nahrworld And Bayhan 2013, 126), the Beyoğlu district is still a cosmopolitan place were "different worlds meet and coexist" (134). And Gezi Park was, as well, a gay-male cruising area:

Both Cairo's Tahrir Square and Taksim Square in Istanbul, with the adjacent Gezi Park, in fact, are known as cruising areas, where gay people meet, make friends, arrange sexual encounters. Gezi Park, which in the light of day is a paradise for families looking for a green corner, at night becomes the republic of a proletarian and almost anarchist homosexuality which prefers the trees along Mete street to chic gay clubs, when in search for a quickie, a male prostitute, a love... (Pier 2013).

In this sense, as the "the biggest 'cruising' spot for the community" (Yildiz 2013), Gezi was already a queer heterotopia before the uprising, if only because "the way it is experienced by the LGBT constitutes a counterhegemonic production of space" (Nahrwolda and Bayhan 2013, 135), that is, a space of otherness and resistance against the heteronormative production of public spaces. Which is not, in any way, independent of the economic life of the neoliberal city:

In order to ensure the "safety" and "well-being" of Turkey's youth and build his "conservative generation" through increased procreation ("at least three children" per couple, he [Erdoğan] repeatedly ordered), Erdoğan commanded that "Beyoğlu had to be cleansed, and the LGBTQ spaces dismantled". In other words, Erdoğan's larger "renewal" project has always been equally interested in generating capital accumulation and heterosexual procreation. (Yildiz 2013).

As a result, the underlying power relationships through which the constitution of public space had taken place in this case had already produced a profound exclusionary impact on diverse minorities before the project of urban renewal. One that echoes similar processes of gentrification in many other cities in which the commodification of public space entails the production of a "safe domestic space, where families can occupy space without the threat of contagion from alternative forms of intimacy" (Bell and Binnie 2000, 95). 
For all these reasons, the presence of the "spontaneously-hung rainbow flag on one of the trees in Gezi Park" from the very beginning of the occupation, which worked as a "mark to find each other [LGBTQ activists] in the crowd", and facilitated "the formation of the LGBT Block" (Okçuoğlu 2013), not only did not come as a surprise, but must be read as a meaningful reminder of the power relationships that were already at stake in the history of the park before the settlement of the Gezi Park encampment.

Once again, the work developed from the space occupied by the LGBT block was, also, bidirectional. They participated in the global resistance against the neoliberal politics that the shopping mall in Beyoğlu had come to symbolize and, at the same time, they carried out inner work within the movement, one that entailed struggling against the use of homophobic slurs in its slogans (successful to the point that "Erdoğan is a fag [ibne]" became "Erdoğan is sexist" (Nahrwold and Bayhan 2013, 136), and building firm bonds of solidarity with the very diverse groups that had joined the protests.

In this case, the impact of their very active presence at the protests, in terms of coalition building, was made evident by the massive participation in both the trans march of 23 June and in the LGBT march of the $30^{\text {th }}$, increasing from around 500 participants to at least 40,000 in 2013, when not 100,000 (Pearce 2014, 116), mostly due, from the point of view of both "organizers and observers", to the "Gezi Park protests that yielded new allies" (117). Both marches have been considered to "signal a historical turning point in the broader legitimacy of LGBT rights in Turkish culture" (111), to the point that the participation of the LGBT bloc at the Gezi resistance is considered, by some, as a "transformative contribution to the collective memory of LGBTQ people in Turkey", which "may have opened up the possibility of thinking what was previously "unthinkable"“" (Okçuoğlu, 2013).

For others, the articulated presence of queer protesters in Taksim Square "was also the first time that the movement received international attention" (Çetin 2016, 6). At the same time, queer participation in the protests would have encouraged a more fluid relationship between LGBTQ activism and political parties since the municipal elections in 2014 (Çetin 2016, 29). In 2013, the Turkish government was even praised by the Commission of the European Parliament in its "Turkey 2013 Progress Report" (COM, 2013, p. 53) for not having "disrupted" these marches, in contrast with the police brutality met by the Gezi protesters during the 
previous month. As is well known, the repression of all forms of political dissent has only worsened during Erdoğan's presidency, starting with the violent repression of LGBT marches and events, as if trying to erase the memory of the firm bonds of solidarity established among queer activists and other repressed groups. Nonetheless, the role played by queer activism both during and immediately following the Gezi Resistance will remain a watershed moment for coalitional politics between queer and non-queer groups in massive citizen protests, one that proves especially useful when it comes to understanding how queer interventions in spaces of protest can alter the inner architecture of the struggle against neoliberal reconfigurations of urban space, revealing the intimate relations between neoliberal urban planning and the dispossession of sexual and ethnic minorities.

\section{Conclusions}

The purpose of this article was not to provide a comprehensive account of queer interventions in the frame of the Occupy movements. That would entail a different kind of inquiry, in which other groups from other protest camps would necessarily be present, such as Queer/LGBTIQA2Z Occupy Wall Street in New York, Homonomixxx and their commitment "to bring well-studied fierceness, anti-oppression ethics, and keen artistic eyes to social justice activism”, to Occupy San Francisco (Letrigre 2011), the Queer Affinity Group at Occupy Los Angeles, the Lesbian, Gay, Bisexual, Transgender and Queer Direct Action Working Group at Occupy Boston (Juris et al. 2012, 438), or People of Color/Queer People of Color in Occupy Oakland, who emphasized the need to strengthen the links between the Occupy movement and "the context of our local, living communities and the ongoing work being done by those communities" (People Of Color Caucus, 2011), among many others. It would include some groups that were not formed during the Occupy movements but which nonetheless established fruitful relationships with it, such as Fierce and Queerocracy in New York, or Queer Resistance in London, and ending -for the time being- with the impact of the Umbrella Revolution on the sixth Hong Kong Pride march, in a way that is strongly reminiscent of the trans and LGBT marches in Istanbul ${ }^{8}$.

The aim of this inquiry was, instead, to explore the ambivalent relationships between queer activism and the spaces of protest in which they intervene. In opposition to the dynamics of queer activism in the 1990s, the presence of queer activists in the counter-globalization movement and, later on, in the global Occupy movements, has developed through increasingly 
complex processes of coalition building, sometimes short-lived, sometimes long-term. What the aforementioned, and many other similar irruptions of queer spaces, exemplifies is the need of certain groups to produce their own spaces of appearance in order to expose and destabilize the constitutive exclusions of the political spaces in which they emerge.

In this sense, the queer spatial politics of protest encampments reminds us of the political ambivalences inherent to the constitution of any space of resistance. Far from allowing us to find comfort in the romanticization of any horizontality or inclusivity of protest space, they have often contributed to the exposure of the exclusionary forces at play in the performative constitution of the collective subjects of political protest. This task entails a somewhat ambivalent relationship with the movements in which they participate, especially when we acknowledge that the premise of radical inclusivity has been one of the mobilizing characteristics of the global Occupy movements. Acknowledging the limits of such a premise or, rather, of such a promise, may well be, in fact, one the most urgent theoretical and political tasks when it comes to helping us reach the utopian goal inscribed in that very promise.

Those are also the same political ambivalences pertaining to the Foucauldian concept of heterotopia, which made it convenient to think of the spatial politics of heterotopias of resistance in the form of encampments as being akin to disciplinary spaces, such as prisons. In a similar manner, occupied heterotopian space is always far more ambivalent than any political slogan such as "We are the 99 per cent", would ever let us think. The critical task of exposing the limitations of the utopian, "inclusive-of-all-differences" representation of the global Occupy movements, (and similar forms of collective protest), entails the recognition of how queer and other minority groups participate within the spatial dramatization of the agonistic character of any transformative, plural democratic project.

\section{Notes}

1] The encampment at Puerta del Sol was, for its part, the result of one of these 'contagions': the influence of the occupation of Tahrir Square was not only evident but even made explicit in some of the billboards of the protesters (Dhaliwal 2012, 255).

2] This is an umbrella term I have borrowed, as vague as it may be, yet one that captures the core spatial trait, from Athena Athanasiou (Atahanasiou and Butler 2013, 154).

3] El País, 15 May, 2015, "La manifestación de 'indignados' reúne a varios miles de personas en toda España" (http://elpais.com/elpais/2011/05/15/actualidad/1305447428_850215.html).

4] I have discussed in greater detail the political ambivalences of the Foucauldian understanding of 
heterotopias and the way human geographers from the Marxist tradition deal with it (see Pérez Navarro, 2014). The way this paper is framed within the arena of heterotopias of resistance, in particular, is indebted to the way Henri Lefebvre makes use of the Foucauldian concept.

5] As Chantal Mouffe expresses it in Derridean terms, in direct relationship with the formation of political identities (Mouffe, 1992).

6] The conclusions of the article provide a (non-exhaustive) list of queer groups that were active within or in the margins of the global Occupy movements.

7] Presented in opposition to Hegel's definition of 'in-itself' phenomena, understood as 'the bare facts' of their 'existence, as disorganized potential' before any processual articulation, 'in both language and being' that can turn them into a 'self-aware and mature force' (LEWIS, 2011, p. 116).

8] Which encourages a reflection on the differences between the synergies established between the protesters and the LGBT pride marches in Istanbul or Hong Kong and the much more critical interventions made in relation to the commodified pride marches of Madrid (which took the form of an alternative Orgullo Indignado) and in different enclaves of the US under the name of Occupride.

\section{References}

Anderson, James, Kiran Bharthapudi and Hao Cao. 2012. "Occupy the Heterotopia." International Review of Information Ethics 18: 150-168.

Athanasiou, Athena and Judith Butler. 2013. Dispossession: The Performative in the Political. Conversations with Athena Athanasiou. Cambridge: Polity Press.

Barber, Elizabeth. 2014. "Hong Kong's Main Democracy Protest Camp Falls with Leading Protest Figures Arrested." Time, December 11, 2014. http://time.com/3629471/hong-kongs-main-democracy-protest-camp-has-fallen-after-75-days/

Barnett, Anthony. 2013. "The Battle for Taksim Square and The Gezi Park Commune." Open Democracy, June 14, 2013. https://www.opendemocracy.net/anthony-barnett/battle-for-taksim-squareand-gezi-park-commune

Bell, David and Binnie, Jon. 2000. The Sexual Citizen: Queer Politics and Beyond. Oxford and Malden: Blackwell Publishers.

Benyoussef, Lamia. 2016. "Gender and the Fractured Mythscapes of National Identity in Revolutionary Tunisia." In Freedom without Permission. Bodies and Space in the Arab Revolutions edited by Hasso, Frances and Salime, Zakia, 51-80. Durham \& London: Duke University Press.

Brady, Miranda and Antoine, Derek. 2013. "Decolonize Wall Street! Situating Indigenous Critiques of the Occupy Wall Street Movement." American Communication Journal, 15 (1): 1-10.

Butler, Judith. 2015. Notes toward a Performative Theory of Assembly. Cambridge, Massachusetts: Harvard University Press.

Carter, Will. 2015. "Suffering and Loss in Istanbul's Transgender Slum." Middle East Eye, July 28, 2015. http://www.middleeasteye.net/in-depth/features/silence-suffering-and-dispossession-istanbul-s-transgender-slum-1343803757

Castañeda, Ernesto. 2012. "The Indignados of Spain: a Precedent to Occupy Wall Street." Social Movement Studies: Journal of Social, Cultural and Political Protest 11 (3-4): 309-319.

Castells, Manuel. 2011. "Conclusions of the Speech of the Sociologist Manuel Castells on \# 15m." Take the Square, October 10, 2011 http://takethesquare.net/2011/10/08/conclusions-of-thespeech-of-the-sociologist-manuel-castells-on- $15 \mathrm{~m} /$ 
Çetin, Zülfukar. 2016. The Dynamics of the Queer Movement in Turkey before and During the Conservative AKP Government. Berlin: German Institute for International and Security Affairs.

COM. 2013. "Turkey 2013 Progress Report." Extract from the Communication from the Commission to the European Parliament and the Council Enlargement Strategy and Main Challenges 20132014.

Dhaliwal, Puneet. 2012. "Public Squares and Resistance: The Politics of Space in the Indignados Movement." Interface: A Journal for and about Social Movements 4 (1): 251-273.

Fiexa, Carles. 2013. "The \#Spanishrevolution and Beyond." Fieldsights - Hot Spots, Cultural Anthropology Online 68. https://culanth.org/fieldsights/68-the-spanishrevolution-and

Foucault, Michel. 1986. "Of Other Spaces.” Diacritics 16 (1): 22-27.

Halvorsen, Sam. 2012. "Beyond The Network? Occupy London And The Global Movement." Social Movement Studies: Journal of Social, Cultural and Political Protest 11 (3-4): 427-433.

Hasso, Frances and Salime, Zakia. 2016. Freedom without Permission. Bodies and Space in the Arab Revolutions. Durham \& London: Duke University Press.

Jaleel, Rana. 2013. "A Queer Home in the Midst of a Movement? Occupy Homes, Occupy Homemaking." In Is This What Democracy Looks Like?, edited by The Social Text Collective, 1-10. New York: Columbia University Libraries. https://academiccommons.columbia.edu/cata$\underline{\log / \mathrm{ac}: 166371}$

Jones, Ángela. 2009. "Queer Heterotopias: Homonormativity and the Future of Queerness." Interalia, 4: $1-20$.

Juris, Jeffrey et al. 2012. "Negotiating Power and Difference within the 99\%" Social Movement Studies: Journal of Social, Cultural and Political Protest 11 (3-4): 434-440.

Lefebvre, Henri. 1991. The Production of Space. Oxford: Blackwell.

Letigre, Toni K. 2011. "Queers Hope for More Presence at Occupy Sf." Edge, November 21, 2011. http://www.ebar.com/news/article.php?sec=news\&article=6216

Lewis, Holly. 2012. "Occupy Gender: How Women and Queer People Find Their Voice in Mass Movements." Journal of Research on Women and Gender 5: 111-132.

Maharawal, Marisa M. 2016. "Occupy Movements." In The Wiley Blackwell Encyclopedia of Gender and Sexuality Studies, edited by Nancy Naples. New Jersey: John Wiley \& Sons, 1-5.

Mouffe, Chantal. 1993. The Return Of The Political, Foreign Affairs. Londres And New York: Verso.

Nahrwold, Judith and Sethen Bayhan. 2013. "Gezi Resistance from a Spatial and Gendered Perspective." Anuari del Conflicte Social 3: 117-151.

Nair, Parvati. 2012. "The Body Politic of Dissent: The Paperless and the Indignant." Citizenship Studies 16 (5-6): 783-792.

Nofre, Jordi. 2013. “Cartografías de la Indignación.”Ar@Cne. Revista Electrónica de Recursos en Internet sobre Geografia y Ciencias Sociales 169. http://www.ub.edu/geocrit/aracne/aracne$\underline{169 . \mathrm{htm}}$

Occuqueers. 2012. "Occuqueers Minutes." Occupy Austin. March 8, 2012. http://Occupyaustin.Org/2012/03/Occuqueers-Minutes-3-7-2012/

Occuqueers. 2012. "Video: About the Do Not Kill List." Occupy Austin. July 31, 2012. http://occupyaustin.org/2012/07/video-about-the-do-not-kill-list/

Oikonomakis, Leonidas and Jérôme E Roos. 2013. “'Que no nos representan' The Crisis of Representation and the Resonance of the Real Democracy Movement from the Indignados to Occupy." Paper presented at 'Street Politics in the Age of Austerity: From the Indignados to Occupy,' 
University Of Montreal. http://media.roarmag.org/2013/02/resonance-real-democracy-movement-indignados-occupy.pdf

Okçuoğlu, Bade. 2013. "The LGBT Block.” Paper Presented at Talk Turkey Conference: Rethinking Life Since Gezi, New School's Historical Studies Department. http://www.jadaliyya.com/pages/index/15037/rethinking-gezi-through-feminist-and-lgbt-perspect

Pearce, Susan C. 2014. "Pride in Istanbul. Notes from the Field: Summer 2013." Sociologists without Borders 9 (1): 111-128.

Pérez Navarro, Pablo. 2014. "Queer Politics of Space in the 15-M Movement." Lambda Nordica 19 (2): 83-114.

Pérez Navarro, Pablo. 2017. "Rosa Parks con Judith Butler: Performatividad individual y acción colectiva." Isegoría 56: 187-204.

People of Color Caucus. 2011. "People of Color/QPOC Meeting." Occupy Oakland, November 27, 2011. https://occupyoakland.org/event/people-of-colorqpoc-meeting-new-times/

Pier. 2013. "LGBT Movement and Global Protests - 2. Turkey." Il Grande Colibri, Omosessualità e interculturalità, July 23, 2017 http://www.ilgrandecolibri.com/2013/07/gay-gezi-protest-turkey.html

Rancière, Jacques. 1999. Disagreement: Politics and Philosophy. Minneapolis \& London: University Of Minnesota Press.

Salime, Zakia. 2016. “'The Women Are Coming': Gender, Space, and the Politics of Inauguration.” In Freedom without Permission. Bodies and Space in the Arab Revolutions, edited by Hasso, Frances and Salime, Zakia, 138-136. Durham \& London: Duke University Press.

Schein, Rebeca. 2012. "Whose Occupation? Homelessness and the Politics of Park Encampments." Social Movement Studies: Journal of Social, Cultural and Political Protest 11 (3-4): 335-341.

Trujillo, Gracia. 2016. "La protesta dentro de la protesta. Activismos queer/cuir y feministas en el 15M." Encrucijadas 12: 1-18.

Trujillo, Gracia, 2017. “40 años después.” CTXT Contexto y acción, June 27, 2017. http://ctxt.es/es/20170621/Firmas/13514/ctxt-orgullo-critico-LGBTI-queer-trans.htm

Yildiz, Emrah. 2013. "Cruising Politics. Sexuality and Solidarity after Gezi." Counter Punch, July 12. http://www.counterpunch.org/2013/07/12/sexuality-and-solidarity-after-gezi/

\section{Biography}

Pablo Pérez Navarro is a researcher at the Center for Social Sciences (CES) of the University of Coimbra, Portugal and holds a PhD in Philosophy by the University of La Laguna, Spain. He was a research visitor at the Center of Lesbian and Gay Studies (CLAGS) of the University of New York and a postdoctoral researcher at the Carlos II University of Madrid. 